\title{
VERTICAL TRANSMISSION OF MYCOPLASMA WENYONII IN CATTLE, SUPPORTED BY ANALYSIS OF THE RIBONUCLEASE P RNA GENE - SHORT COMMUNICATION
}

\author{
Fumina SASAOKA $^{1+}$, Jin SUZUKI $^{1+}$, Toh-Ichi HIRATA ${ }^{2}$, Toshihiro ICHIJO ${ }^{1}$, \\ Kazuhisa FurUHAMA ${ }^{1}$, Ryô HARASAWA ${ }^{1}$ and Hiroshi SATOH ${ }^{1 *}$ \\ ${ }^{1}$ Cooperative Department of Veterinary Medicine, Iwate University, 3-18-8 Ueda, \\ Morioka, Iwate 020-8550, Japan; ${ }^{2}$ Field Science Center, Faculty of Agriculture, \\ Iwate University, Shizukuishi, Iwate, Japan
}

(Received 11 March 2015; accepted 22 June 2015)

The vertical transmission of Mycoplasma (M.) wenyonii was investigated in beef cattle raised on a farm in Japan by analysing the ribonuclease P RNA $(r n p B)$ gene sequence using PCR. Peripheral blood samples from 17 dams infected with $M$. wenyonii and from their neonatal calves were collected and colostrum samples were taken from cows immediately after parturition, and subsequently the blood samples of calves were monitored continuously for three months. At birth on day 0, although no $\operatorname{rnpB}$ gene was detected in the colostrum of any of the dams, four $(23.5 \%)$ of the 17 calves born were positive. At three months after delivery, the number of positive calves decreased to three. Although horizontal transmission by blood-feeding arthropod vectors has been basically accepted as the most common route of haemoplasma infection, these findings suggest that vertical transmission is, at least in part, another most likely route of $M$. wenyonii infection in cattle. RNA

Key words: Cattle, haemoplasma, Mycoplasma wenyonii, ribonuclease $\mathrm{P}$

Haemoplasmas (haemotropic mycoplasmas) are causative agents of infectious anaemia in mammalian species including humans (Steer et al., 2011). The microbiological investigation of haemoplasmas has been hampered by the lack of appropriate means to grow them in vitro. In cattle, two distinct species, i.e. $M y$ coplasma (M.) wenyonii and 'Candidatus M. haemobos' (synonym of ' $C a$. M. haemobovis') have been recognised as causative agents of bovine infectious anaemia (Tagawa et al., 2008).

The routes of haemoplasma infection in cattle have not yet been fully revealed. Therefore, to elucidate the route of transmission to neonatal calves, we

\footnotetext{
${ }^{+}$These authors contributed equally to this work and should be considered joint first authors; *Corresponding author; E-mail: satohsss@iwate-u.ac.jp; Phone: +81 (19) 621-6981; Fax: +81 (19) 621-6981
} 
studied the presence of the ribonuclease P RNA $(r n p B)$ gene sequence of haemoplasmas in peripheral blood samples of neonatal calves and their dams, as well as in colostrum samples obtained from these cows.

Seventeen cows of the Japanese Black Wagyu beef cattle breed that had been expected to give birth within six months on the research farm at Omyojin of Iwate University (Shizukuishi, Japan) were selected on the basis of the preliminary diagnosis of $M$. wenyonii infection using real-time PCR for the 16S rRNA genes. The cows grazed freely outside in the summer and were housed for about one month before the expected day of delivery. All experimental procedures were performed in accordance with the Guidelines for Animal Experimentation issued by the Japanese Association for Laboratory Animal Science (1987) and approved by the Animal Experimental Ethics Committee of Iwate University.

Anti-coagulated blood and colostrum samples were collected from the cows and their neonatal caves. Total DNA was extracted from $200 \mu \mathrm{l}$ of the whole blood or colostrum samples by using the QIAamp DNA Blood Mini Kit (QIAGEN, Hilden, Germany) according to the manufacturer's instructions, eluted into $200 \mu \mathrm{l}$ of sterile distilled water, and stored at $-20^{\circ} \mathrm{C}$ until testing. Haemoplasma infection was diagnosed using real-time PCR as described previously (Nishizawa et al., 2010).

Another gene $(r n p B)$ was also examined to confirm M. wenyonii infection in the positive samples using end-point PCR assay because this particular gene has been used for the differentiation of closely related haemoplasma species. For example, M. haemofelis and M. haemocanis are difficult to distinguish by the nucleotide sequence of the 16S rRNA gene, but they have been established as distinct species on the basis of differences of the $r n p B$ gene sequences (Messick et al., 2002) in the Haemofelis cluster (Birkenheuer et al., 2002). The end-point PCR for the $r n p B$ gene was performed with forward primer rnpB-F, 5'-AGTCTG AGATGACTRTAGTG-3' equivalent to nucleotide numbers 1 to 20 of $M$. wenyonii (EU078610) rnpB gene and reverse primer rnpB-R, 5'-TRCTTGMGGGGT TTGCCTCG-3' equivalent to nucleotide numbers 170 to 189 of $M$. wenyonii (EU078610) rnpB gene. The PCR was carried out in a reaction containing $2 \mu 1$ of DNA solution, $0.5 \mu \mathrm{l}$ of TaKaRa EX Taq (5 units/ $\mu$ l), $5 \mu \mathrm{l}$ of 10X EX Taq buffer, $4 \mu \mathrm{l}$ of dNTP mixture (2.5 mM each), $0.2 \mu \mathrm{l}$ of forward, reverse primers $(50 \mathrm{pmol} / \mu \mathrm{l}$ each), and distilled water (to a final volume of $50 \mu \mathrm{l})$. After overlaying with $20 \mu \mathrm{l}$ of mineral oil, the reaction was carried out 35 times with denaturation at $98{ }^{\circ} \mathrm{C}$ for $10 \mathrm{sec}$, annealing at $55^{\circ} \mathrm{C}$ for $60 \mathrm{sec}$, extension at $72{ }^{\circ} \mathrm{C}$ for $60 \mathrm{sec}$ after the initial denaturation at $94^{\circ} \mathrm{C}$ for $120 \mathrm{sec}$ and finally further extension at $72{ }^{\circ} \mathrm{C}$ for $300 \mathrm{sec}$ in a thermal cycler. Following the amplification, $10-\mu 1$ aliquots of the PCR products were mixed with $2 \mu \mathrm{l}$ of $6 \mathrm{X}$ dye solution consisting of $0.25 \%$ xylene cyanol, $0.25 \%$ bromophenol blue and $40 \%$ sucrose in water. The PCR products were fractionated on horizontal, submerged $1.0 \%$ SeaKem ME agarose gels (FMC Bioproducts, Rockland, MA, USA) in TAE (40 mM Tris, 
$\mathrm{pH}$ 8.0, $5 \mathrm{mM}$ sodium acetate, $1 \mathrm{mM}$ disodium ethylenediaminetetraacetate) buffer at 50 volts for $60 \mathrm{~min}$. After electrophoresis, the gels were stained in ethidium bromide solution and visualised under UV transilluminator. DNA in a clearly visible band was extracted by using NucleoSpin Extract II kit (MachereyNagel, Düren, Germany) and was subjected to direct sequencing in a $3500 \mathrm{Ge}-$ netic Analyzer (Applied Biosystems, Foster City, CA, USA).

In repeated real-time PCR assays, 17 cows were confirmed to be positive for $M$. wenyonii infection. The DNA of $M$. wenyonii was not detected in any of the colostrum samples. The positivity rate for $M$. wenyonii infection was $23.5 \%$ (4 out of 17) in 0-day-old neonatal, $11.8 \%$ ( 2 out of 17 ) in two-day-old, $17.6 \%$ (3 out of 17) in one-month-old, and 17.6\% (3 out of 17) in three-month-old calves. Remarkably, the nucleotide sequence of the $r n p B$ gene in all neonatal calves infected with $M$. wenyonii was identical to that found in their dams.

Four calves designated $4 \mathrm{c}, 5 \mathrm{c}, 14 \mathrm{c}$ and $21 \mathrm{c}$ were $M$. wenyonii positive at birth, and a calf designated $3 \mathrm{c}$ became infected with $M$. wenyonii after three months (Table 1). Among them, two calves designated 14c and 21c, became negative for $M$. wenyonii infection on day two after birth, but became positive again by the age of three months old. The incidence of persistence and bacteraemia in calves under three months of age calves was inconsistent, despite the lack of development of clinical signs or medical attendance.

Table 1

Occurrence of Mycoplasma wenyonii in the peripheral blood of calves from infected cows

\begin{tabular}{lcccc}
\hline Designation & Day 0 & Day 2 & 1 month later & 3 months later \\
\hline $3 \mathrm{c}^{*}$ & - & - & - & + \\
$4 \mathrm{c}$ & + & + & + & + \\
$5 \mathrm{c}$ & + & + & + & - \\
$14 \mathrm{c}$ & + & - & + & - \\
$21 \mathrm{c}$ & + & - & - & + \\
\hline
\end{tabular}

*c: calf, + : positive, - : negative

The laboratory diagnosis of haemoplasma infection is usually based on the examination of blood smears, PCR, ELISA or Western blotting. Of these tests, PCR is most widely used. Two conserved nucleotide sequences, the 16S rRNA and $r n p B$ genes, have preferably been used in specific PCR diagnosis for haemoplasma infections, and haemoplasmas have been classified into Haemominutum and Haemofelis clusters based on phylogenetic analyses of these sequences (Peters et al., 2008).

The routes of haemoplasma infection in cattle remain unknown, although vector-borne transmission by blood-sucking arthropods has been suspected as a primary mode of dissemination of haemoplasmas in cattle during summer graz- 
ing (Hofmann-Lehmann et al., 2004). On the other hand, the transplacental transmission of haemoplasmas has been suggested because precolostral blood samples taken at birth from neonatal calves born to affected mother animals were already positive for haemoplasma infection (Hornok et al., 2011). Our results suggest that the vertical transmission of bovine haemoplasmas can be revealed by analysing the nucleotide sequence of the $\operatorname{rnp} B$ gene.

In conclusion, transplacental or intrauterine transmission was thought to be the most probable route of bovine haemoplasma infection in this study.

\section{References}

Birkenheuer, A. J., Breitschwerdt, E. B., Alleman, A. R. and Pitulle, C. (2002): Differentiation of Haemobartonella canis and Mycoplasma haemofelis on the basis of comparative analysis of gene sequences. Am. J. Vet. Res. 63, 1385-1388.

Hofmann-Lehmann, R., Meli, M. L., Dreher, U. M., Gönczi, E., Deplazes, P., Braun, U., Engels, M., Schüpbach, J., Jörger, K., Thoma, R., Griot, C., Stark, K. D. C., Willi, B., Schmidt, J., Kocan, K. M. and Lutz, H. (2004): Concurrent infections with vector-borne pathogens associated with fetal hemolytic anemia in a cattle herd in Switzerland. J. Clin. Microbiol. 42, 3775-3780.

Hornok, S., Micsutka, A., Meli, M. L., Lutz, H. and Hofmann-Lehmann, R. (2011): Molecular investigation of transplacental and vector-borne transmission of bovine haemoplasmas. Vet. Microbiol. 152, 411-414.

Messick, J. B., Walker, P. G., Raphael, W., Berent, L. and Shi, X. (2002): 'Candidatus Mycoplasma haemodidelphidis' sp. nov., 'Candidatus Mycoplasma haemolamae' sp. nov. and Mycoplasma haemocanis comb. nov., haemotrophic parasites from a naturally infected opossum (Didelphis virginiana), alpaca (Lama pacos) and dog (Canis familiaris): phylogenetic and secondary structural relatedness of their 16S rRNA genes to other mycoplasmas. Int. J. Syst. Evol. Microbiol. 52, 693-698.

Nishizawa, I., Sato, M., Fujihara, M., Sato, S. and Harasawa, R. (2010): Differential detection of hemotropic Mycoplasma species in cattle by melting curve analysis of PCR products. J. Vet. Med. Sci. 72, 77-79 (Erratum, J. Vet. Med. Sci. 72, 1704).

Peters, I. R., Helps, C. R., McAuliffe, L., Neimark, H., Lappin, M. R., Gruffydd-Jones, T. J., Day, M. J., Hoelzle, L. E., Willi, B., Meli, M., Hofmann-Lehmann, R. and Tasker, S. (2008): RNase P RNA gene (rnpB) phylogeny of hemoplasmas and other Mycoplasma species. J. Clin. Microbiol. 46, 1873-1877.

Steer, J. A., Tasker, S., Barker, E. N., Jensen, J., Mitchell, J., Stocki, T., Chalker, V. J. and Hamon, M. (2011): A novel hemotropic Mycoplasma (hemoplasma) in a patient with hemolytic anemia and pyrexia. Clin. Infect. Dis. 53, 147-151.

Tagawa, M., Matsumoto, K. and Inokuma, H. (2008): Molecular detection of Mycoplasma wenyonii and 'Candidatus Mycoplasma haemobos' in cattle in Hokkaido, Japan. Vet. Microbiol. 132, 177-180. 